\title{
Customer Delight Strategy in Hotel Industry
}

\author{
L. A. Wibowo, J. J. P. Ekaputri \\ Faculty of Economic and Business Education \\ Universitas Pendidikan Indonesia \\ liliadiwibowo@gmail.com
}

\begin{abstract}
Low customer loyalty is a significant issue in hotel industry. Every hotel faces the same problem that is to keep their customers loyal. It is important since the customers are assets for the hotels. Therefore, retaining customers, which is easier and cheaper, should give some more importance than acquiring new ones. It is not an easy job when there is competition between hotels trying to keep their customers loyal. Grand Royal Panghegar Hotel is one of the hotels facing the low customer loyalty problem. Thus, this research aims to know the influence of good service to customer loyalty. This research employs descriptive and verifiable method and examines 100 hotel customers by employing Partial Least Square Methode (PLS) analysis technic. The results show that customer delight strategy has a significant contribution to customer loyalty. The most important factor contributing to the customer loyalty is trust that is needed to build a strong relationship between hotel and its customers. Meanwhile, justice becomes a factor that gives low contribution to loyalty. This aspect must be improved by providing fair treatment for the customers who stay and do transaction at the hotels.
\end{abstract}

\section{Keywords: customer delight, customer loyalty}

\section{INTRODUCTION}

Low customer loyalty is a significant issue in hotel industry. Every hotel faces the same problem that is to keep their customers loyal. A survey conducted by Deloitte (Traveler Survey Findings) in 2013, displays that only $7,8 \%$ customers who decide to stay at the same hotel. There is a tendency that they are not interested in joining loyalty membership programs offered by many hotels. In other words, the tendency depicts low customer loyalty to hotel industry. Regarding the issue mentioned above, literature shows that there have been some research studies investigating customer loyalty.

A research conducted by Gilies (2005:1) shows that global economy development contributes to massive competition of hotels in Ghana. The growing hotel industry gives customers, who like to try something new, many choices. It effects on the tendency that they will not stay at the same hotel. Many loyalty membership programs offers make the customers register themselves for membership. However, the fact shows that they are reluctant to extend their membership in the following year.

Fei Teng (2010:5) also investigates hotel customer loyalty. The result shows that to face hotel industry competition involving international and national chain hotels, a hotel must prepare the right program and strategy to keep their customers loyal.
Those research studies and surveys depict how the customers tend to stay at different hotels instead of being loyal to one hotel only. Hence, the low loyalty of the customers become an issue faced by many hotels. The low customer loyalty effects on the hotel's profitability. The disloyal customers tend to choose the product or service offered by the competitors. A five stars hotel has a marketing strategy to face the competition of acquiring customers based on segmentation and target customers that must be achieved.

The number of hotels allows customers to stay at different hotels every time. Therefore, each hotel must have a good strategy that can show their distinctive quality from the others in order to retain the customers. This phenomenon also happens in Indonesia where hotels build more rooms to fulfill the growing demand from public. However, the high demand does not guarantee the customers to be loyal to one hotel. In addition, the competition makes it harder to retain the customers.

Grand Royal Panghegar Hotel, a hotel in Bandung, is one of the hotels that faces the same problem. This low customer loyalty should be overcome if the hotel does not want to be left behind. The growing hotel industry in Bandung forces every hotel to make an innovation and strategy to hold their business afloat. Therefore, Grand Royal Panghegar Hotel applies customer delight strategy that is suitable to retain the customers who look for memorable experiences. These experiences will be special memories that make them feel attached to the hotel.

By using this strategy, the hotel can increase the customers' loyalty so they will not defect to competitors' service and product. In addition, the strategy also provides positive word of mouth publicity regarding the hotel's product and service. However, the influence of customer delight strategy to customer loyalty is still in question. Thus, a research investigating customer delight strategy in hotel industry is needed.

\section{CUSTOMER DELIGHT AS A STRATEGY TO INCREASELOYALTY}

Marketing is defined as "a societal process by which individuals and groups obtain what they need and want through creating, offering, and freely exchanging products and services of value with others" (Kotler Keller 2012:5).

Tourism has a close relationship with marketing concept. Yoeti (1996:35) asserts that tourism marketing in general can be defined as an activity where demand meet supply. The aim of the activity is to make the customer satisfied in one hand and give the company maximum profit with minimum risk on the other hand. In 
marketing concept, customer needs to be satisfied, thus marketing concept emphasizing customers' satisfaction is expected to increase their loyalty. Jones and Sesser (1997 in Kwong \& Yau, 2002;255) suggest that satisfied customer (not completely satisfied) give negative comment to some aspects of a product. Hence, a sufficient marketing strategy is needed to satisfy the customers and increase their loyalty. Kotler and Armstrong (2012:48) explain that marketing strategy is "the marketing logic by which the business unit hopes to create customer value and achieve profitable customer relationships".

Further research explains that making customers satisfied is not enough, since the company should make the customers feel completely delighted. Thus, the research asserts a higher level of satisfaction that is besides being satisfied, the customer should be delighted. This level of satisfaction that increases customers' loyalty for the company is called "customer delight".

Customer delight is constructed as a nonlinear relationship between satisfaction and customer loyalty. This concept explains why a satisfied costumer may defect because satisfaction does not guarantee patron for money purchase. Thus, the research studies about customer delight represent that the application of customer delight strategy can be used as an advantage for the company to increase customer loyalty.

Using customer delight strategy is an important asset for a company. Berman (2005:140 in Stromberg

\& Frisk, 2011:3) explains that when the higher value of customer satisfaction is reached, the company can make the same value as many as eleven customer who are merely loyal. It is not only caused by how the customer will return to purchase the company's service again but the customer is expected to do the company a great service by offering favorable word of mouth publicity such as telling friends and family. As the result, it brings the company a huge profit.

The dimensions used for this research are justice, esteem, security, trust, and variety (Kwong \& Yau, 2002:262). Those dimensions are chosen since they fit the strategy the company applies to build customer delight.

Having loyal customer is an important asset for hotels. Retaining customers, which is easier and cheaper, should give some more importance than acquiring new ones. There are many benefits from having loyal customers. Loyalty, in business context, means a will from the customer to buy the service or the product from a company continually over a long period and recommend the service or the product to his/her friends and family. The customer loyalty is not only restricted to the customer behavior. It includes preference, liking, and future intensions (Lovelock, 2012:360). The loyalty dimensions used in this research are building a foundation for loyalty, creating loyalty bonds, dan reducing churn drivers (Lovelock, 2012:365)

The proposed hypothesis of this research is the dominance factors influencing customer delight and the significant effect between customer delight and customer loyalty. It supported by a premise asserted by Berman (2005:140 in Stromberg \& Frisk, 2011:3) who says, "When succeeding to create a delighted customer, the organization can generate the same lifetime values of as many as eleven customers who are merely loyal".

\section{RESEARCHMETHODOLOGY}

This research investigates customer delight strategy and its influence to hotel customer loyalty through marketing management approach. The independent variable of this research is customer delight (X) comprising of justice, esteem, security, trust, variety. Meanwhile the dependent variable is customer loyalty (Y) comprising of building a foundation for loyalty, creating loyalty bonds, reducing churn drivers.

Based on the aim and the variables stated above, this research is categorized as a descriptive and verifiable research. This research tests the hypothesis of the influence of customer delight in raising customer loyalty by surveying the hotel customers.

In line with the nature of the research, the unit of the analysis is the loyalty program members. Meanwhile, since this research is categorized as descriptive and verifiable research, explanatory survey is used to get a general description of customer delight, loyalty, and dominant factors building customer delight and its influence to loyalty.

The population of this research is the loyalty program members. The samples, comprised of 100 respondents, are calculated by using Solving formula. The sampling technique employed is simple random sampling while the data collection techniques used are observation, interview, questionnaire, and literature study. In addition, the research applies Partial Least Square (PLS) method as the data analysis and hypothesis testing technique. PLS is used to confirm the theory by verifying the relation between the latent variables. PLS can be used to simultaneously analyze the built constructs through reflective and formative indicators which is impossible to do in SEM because of the unidentified model.

The figure below shows customer delight and loyalty equation model:

Customer loyalty $=0,76076504190734 *$ Customer Delight

\section{FINDINGS \& DISCUSSIONS}

Based on the output of XL-STAT 2015 program that is $\mathrm{t}-$ count $=12,181$ and $\mathrm{p}$-value $0,000<0,05$, the result shows positive influence of customer delight on loyalty. This research discusses the factors building customer delight and its influence on loyalty. The result of the hypothesis testing shows that $\mathrm{t}-$ statistic score for customer delight variable is 12,181 with $p$-value $0,000<0,05$. Therefore, it could be argued that the customer delight comprising of justice, security, trust, and variety has positive influence on the loyalty program members. The test results of discriminant validity or loading factor of each customer delight variable dimension also shows good scores which means there is a correlation between the dimensions and loyalty.

The contribution of customer delight variable to loyalty can be seen from the coefficient value, as follows: 


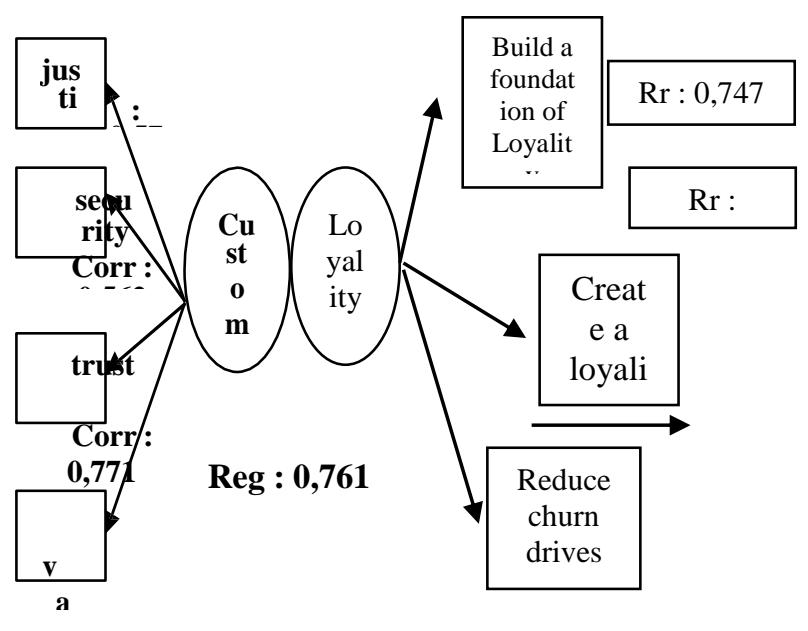

Cor: 0,94

Fig. 1. Source : XLSTAT PLS-PM 2014-2015 data result

Justice has $0,573>0,5$ loading factor value that is categorized as the factor influencing loyalty. Meanwhile, the simultaneous test between customer delight variable and loyalty is depicted by statistic $\mathrm{F}$ with $0,000<0,05 \mathrm{p}$ value. The results show that customer delight variable simultaneously influence the customer loyalty. The results represent a significance positive influence between two variables.

Since the customer delight hypothesis is accepted, the research proves Stromberg (2011:253) theory that companies make the customers delighted by delivering the services as have been promised then exceeding these customers' expectations. The logic behind the statement is that a company may win a customer's heart if he/she feels delighted continuously.

Customer delight gives the customers deep impressions and makes them feel delighted. If it happens continuously, it can build and increase the customer loyalty. Based on the results above, it is certain that customer delight comprising of justice, security, trust, and variety gives contribution to $\mathrm{R}^{2}$ as big as $100 \%$ to loyalty.

The contribution to the $\mathrm{R}^{2}$ value based on the loading factors value between customer delight and loyalty is $0,761>0,7$ and it is categorized into high and ideal influence. Therefore, it is concluded that customer delight has a significant effect to the loyalty of the hotel customers especially to improve the loyalty of the loyalty program members. Justice, security, trust, and, variety factors help the customers to be delighted while staying in the hotel. Therefore, trust dan variety are the dominant factors influencing customer delight and customer loyalty.

Trust in delighting the costumers refers to the best crisis management in which the hotel admit errors made and takes full responsibility for it (Kwong dan Yau, 2002), whereas variety is a factor relevant to every "demanding" behavior of the customers. Since they always demand something new, the hotel should have the ability to delight them by producing new products/service or a new program that will give them pleasant surprises. By doing so, the hotel will win the customers' hearts (Kwong \& Yau, 2002;262).
By making the customers believe in the hotel, the customers are assured that the hotel will give them the best service and as the result they will return to purchase the hotel's service again. In addition, by giving a variation in the hotel's service/product/program, the customers will not feel bored while staying at the hotel. This will effect to the profit of the hotel since they will recommend the hotel to their friends and family to stay at the same hotel or even join the loyalty program membership too.

\section{CONCLUSION \& SUGGESTIONS}

Based on the result of the descriptive and verifiable analysis by employing Partial Least Square (PLS) method, it can be concluded that the factors building customer delight and its influence to loyalty is that the customer delight variables have high values for the customers. The dimension with the highest score that builds and influences loyalty is trust. It is caused by the hotel's ability to gain the customer's trust. The implementation of trust in the hotel is when the hotel is responsible for all services and does further action to anticipate complains. In addition, the hotel also fulfills its promises by providing the services as has been promised such as gives the rights or advantages that should be gotten by the members. The hotel also tries to give the best service and to realize every program in order to make the customers believe that the hotel does not lie to them and further make them believe and feel that they are attached to the hotel.

The customers' responses regarding the loyalty comprising of building a foundation of loyalty, creating a loyalty bonds, and reducing churn drivers are quite high. The highest contribution is shown by reducing churn drivers. It is caused by the fact that the hotel always tries to give the best service. As the result, it minimizes the chance that the members will be disappointed while staying there. The delighted members increase their loyalty to the hotel. This research shows that customer delight strategy comprising of justice, security, trust, and variety has a positive and significant effect to the loyalty of the customers.

Overall, customer delight practice in the hotel is seen as a good effort by the respondents. The implementation of customer delight strategy comprising of justice, security, trust, and variety should be improved especially the justice and security aspect which do not reach ideal values. For the justice aspect, the hotel can improve it by assuring a fair agreement in every transaction, for instance, by making innovation for product and program. In addition, the members should be given various choices related to the product and program also freedom to choose program and product which is appropriated with the members' needs. Meanwhile for the security aspect, the hotel should improve the secured feeling for the members by assuring that their importance are protected.

Most of the customers do not want to extend their membership in the following year. The questionnaire data reveals that some respondents do not feel satisfied and they do not get the benefit by being the loyalty program member. Therefore, some improvement should be made, for instance, hotel should improve the benefits given by ensuring that the distinctive 
requirements of all members are fulfilled, improve the employees' performance so the they give their best services for the members. In addition, the service for the member should be special compared to the normal customers, assurance while doing transaction, make the member feels that they get benefits and make them feel delighted. The hotel also should ensure the customers' comfort and security. Their needs should also be fulfilled while staying at the hotel by giving them easy access. It can be realized by giving them their personal service operator like have been done by some big hotels in Indonesia. Hotel can make Fast Response Service (FRS) which is programmed to give a good and fast response for the customers' needs and complains. As the result, their complains and needs can be handled well and quickly. The hotel can also make an event and give periodic promos (not only the written program and promos) in order to give them surprise so they will extend their memberships in the next period.

\section{REFERENCES}

[1] A, Yoeti, Oka. 1996. Pengantar Ilmu Pariwisata. Edisi Revisi. Penerbit Angkasa, Bandung

[2] Gillies, Luke, Tomoko, Kitamura, Maki, Yokota. 2005. Adding Value to Hotel Loyalty Programs for both Guest and Hotel. Tourism and Hospitality Management Master Thesis. Goteborg University.

[3] Kwong, Kenneth K, Yau, Oliver. 2002. The Concetualization of Customer Delight: A Research Framework.

[4] Kotler, Philip, Armstrong, Gary. 2012. Principles of Marketing 14 th Edition. Prentice Hall, New Jersey.

[5] Kotler, Philip, Keller, Kevin. 2012. Marketing Management 14th Edition. New Jersey: Pearson International Edition Prentice Hall.

[6] Lovelock, Christopher, Jochen Witz, Patricia Chew. 2012. Essentials of Service

[7] Marketing. 2nd Edition. Singapore: Prentice Hall

[8] Stromberg,Michaela, Lina, Frisk. 2011. Delighting the Customers, How Costumers Get Their Expectations Exceeded. Lulea University of Technology, Department of Business Administration.

[9] Teng, Fei. 2010. Loyalty Card Promotional Activity in Budget Hotel. Master Thesis D- level, KarlstadUniversity 